\title{
Inside Out or Outside In? Translating Margins, Marginalizing Translations. The Case of Francophone Pacific Writing
}

\author{
Jean Anderson \\ Victoria University of Wellington
}

'... one large bole on the other side of the world...'

The literary world does not offer an even playing field to all writers, this much is clear, and the chances of major literary success vary depending on (among other factors) whether the author is operating within an existent well-established system or must somehow create not only the literary work but the audience for it as well. Texts that are original in their linguistic and cultural difference, their otherness and 'outsiderness', may be acclaimed for that originality, or rejected as inferior precisely because they do not fit with the expectations of publishers and readers in the new, host culture. The exceptional impact of Derek Walcott, for example, (Nobel Prize 1992) or to a lesser degree Patrick Chamoiseau (Prix Goncourt 1992) can be considered in this respect. It is possible to see these two writers from minority literatures (and cultures) working in major world languages as demonstrating the existence of a world literary system that acknowledges talent wherever it may manifest itself; however in both cases there is a strong pioneering element about their work that must also be acknowledged. Their shared design was to represent their Caribbean island culture through both content and form, 'inventing' a literary language to do so. Yet achieving this aim relies on the receiving culture's willingness to read differently, to share the unfamiliar from the inside out, rather than from the outside in-that is, to move somehow beyond the stereotypes and commonplaces of exoticism, both attractive and repellent, that are inevitably part of the non-local reader's baggage. ${ }^{1}$ To put it another way, the reader must be able to decentre his or her reading habits and attempt to understand the text on its own terms, as far as possible within its own context, to mentally overcome the stereotyped notion of a marginal text from a marginal, 'other' world.

In short, the reader - and the translator, as we shall see, as well as the reader of a translated text-is positioned between two essentially conflicting impulses: on the one hand, to be de-familiarised, to discover something new and different, whose attraction resides precisely within that newness and difference, and on the other, to familiarise, to assimilate by recognising the 'universal,' the 'human,' the 'international,' or, alternatively, the already accepted, often stereotyped concepts of the exotic that are associated with the source culture. The dual nature of this latter assimilation process cannot be too strongly

\footnotetext{
${ }^{1}$ We should note that many reviews and critical studies appear more focused on the author's individual creativity, the Romantic notion of individual 'genius', or on reading a work within a European framework, than on pursuing the question of characteristics that might pertain to an entire culture. See for example Noémie Auzas, Chamoisean on les voix de Babel (Paris: IMAGO, 2009): while ostensibly exploring the possibility that the author is attempting to reflect a socio-cultural reality (p. 75), the critic has already assimilated his project to the Judeo-Christian tradition (the tower of Babel).
} 
stressed, for it is often a key factor in determining which texts are selected for translation, and figures largely in many reviews of these translations.

Along with the Caribbean, the Pacific is a region that is typically viewed through a pre-determined and stereotyping lens - when it is viewed at all, that is. Robyn Bargh of Huia Books, a New Zealand publisher focusing on indigenous fiction, remarked following a recent visit to the Frankfurt Book Fair, "We discovered that from Europe ... the Pacific is seen as one large hole on the other side of the world, about which readers know very little." 2 Europeans are not alone in their lack of knowledge of the Pacific. From a North American point of view, awareness is generally lacking that the Pacific and the Pacific Rim are not one and the same. Ironically, here the margins (countries bordering the Pacific) dominate the centre (of the Pacific), precisely because to the perceiving (non-Pacific) culture, those margins are in a sense the limits of the known, with anything beyond that point constituting the 'hole' referred to by Bargh.

The view from some of the Pacific's more developed countries (New Zealand, Australia), also on the rim, is not very different, however. Andreas Reitzig, a New Zealand-based specialist in Pacific Studies, commented at a 2011 seminar that although the country's national identity has become more South Pacific-focused over recent years, it is questionable how much New Zealanders actually know about the region, in other words, how "Pacific literate" they are. ${ }^{3}$

What might the concept of literacy mean in this sense? I am suggesting here that the term refers to the ability to read from the inside out, based on knowledge of the text's original context, or on the willingness to suspend the appropriating, familiarising instinct and encounter the writing as far as possible on its own terms. Whether viewed from near (New Zealand) or far (Europe, North America), the Pacific Ocean and its many nations do indeed appear marginal. My aim is to explore not just the difficulties faced by Pacific authors, specifically those writing in French and from French Polynesia, but to examine ways in which literary translation might allow a better understanding of these very minor ${ }^{4}$ but no less important and interesting literatures.

\section{The literary Pacific}

Where Pacific literature is concerned, there are a number of obstacles to its being read without being familiarised: weighing heavily in the balance, alongside a background lack of knowledge of the region and its many nations and cultures, are the many outsider narratives, from the earliest European 'discoverers' (such as Cook, Banks, Bougainville) to more contemporary times (Stevenson, Brooks, Maugham, Loti, Simenon). Over 200

\footnotetext{
2 BPANZ, 'Featured Members: Robyn Bargh.' http://bpanz.org.nz/cms/index.php?option=com content\&view $=$ article\&id=149:featured-member-robyn-bargh-huiapublishers\&catid=23:members \&Itemid=56, accessed 12 January 2012.

3 Andreas Reitzig, 'National Identity and New Zealand's Ties With Oceania,' Seminar, April 13, 2011, Victoria University of Wellington.

${ }^{4}$ See Gilles Deleuze and Félix Guattari, Mille Plateaux or Gilles Deleuze, Félix Guattari, Robert Brinkley, 'What is a Minor Literature?' Mississippi Review, Vol. 11, No. 3, (Winter / Spring, 1983), p. 13-33. http://www.jstor.org/pss/20133921, accessed 10 December 2011.
} 
years of reflection on the erotic/paradisiac or primitive/cannibalistic nature of Pacific Island cultures have created a highly familiar Europeanised imaginary. ${ }^{5}$ To write from these islands is clearly a major challenge for authors wishing to portray in authentic, 'insider' terms the culture they know and live in. This is particularly the case for indigenous authors for whom there are often few models to follow. We should note here that the publication of literary works by indigenous writers is a relatively recent phenomenon: the 'first' indigenous-authored novel ${ }^{6}$ from New Zealand is Witi Ihimaera's Tangi, dated 1973. For comparison, French Polynesia's first indigenous novelist is Chantal Spitz, with L'Île des rêves écrasés (1991); New Caledonia's is Déwé Gorodé with L'Épave (2005).

There are other, more concrete challenges, too. Literature by Pacific writers, unless they are located in New Zealand or Australia, and write in English, is published in very small print-runs, often well under 1000 copies. Authors from the French-speaking Pacific face a number of potentially even greater challenges. The ocean, although criss-crossed in earlier times by trade routes and migrations, ${ }^{7}$ is in today's faster-paced world an obstacle. For example, although both are part of French Polynesia, Tahiti and the Marquesas are some 900 miles (1500 kilometres) apart, with few connections via air and sea. Although email has made it easier to communicate for the sending of manuscripts, proofs and corrections, the latter stages of publishing a book are more challenging. Distance and the concomitant expense for distribution are not the only problems for francophone Pacific writers. French Polynesia has a total population of some 287,000, and eight publishing houses, only one of which has more than 100 titles, not all literary, on its list. ${ }^{8}$ In New Caledonia, with a population of 227,000 , the only medium-sized publisher closed down recently, leaving around thirty very small houses (five to ten titles). ${ }^{9}$

The majority of French-language writers from the Pacific, and their local publishers, must then for obvious commercial reasons write not just for local readers, but reach beyond the limited and difficult local market to mainland France. This can lead to a kind of dual perspective in their books, aiming to tell stories which arise from a particular context (their centre) in such a way that they can also be read by a distant readership (their margin). ${ }^{10}$ Or, of course, we could invert this schema into a colonial one: the books come into existence on the margin, and are to be read by the centre. This is, to a great

\footnotetext{
5 To illustrate this we need look no further than the outcry over the disappearance of tourist Stefan Ramin in the Marquesas in October 2011: media reports quickly focused on possible cannibalism. (See for example http://www.telegraph.co.uk/news/worldnews/australiaandthepacific/frenchpolynesiatahiti/ 8830733/Cannibal-fear-over-German-tourist.html, accessed 10 December 2011).

${ }^{6} \mathrm{I}$ am here, for the sake of convenience, taking the novel as a marker of 'serious' literary output, although I am aware that this is to apply a Eurocentric measure.

${ }^{7}$ See Epeli Hau'ofa's essay, 'Our Sea of Islands,' in E. Waddell, V. Naidu \& E. Hau'ofa, eds. A New

Oceania: Rediscovering Our Sea of Islands. Suva: University of the South Pacific Press, p. 2-16.

${ }^{8}$ Of the others, five have published five or fewer titles, two have about fifty in their catalogue, and one has brought out around twenty. (Source: personal communication from Christian Robert, President, Association des Editeurs de Tahiti et ses îles (AETI), December 2010).

${ }^{9}$ Source: personal communication from Christian Robert, President, AETI, December 2010.

${ }^{10}$ See Jean Anderson, 'Seeing Double: Representing Otherness in the Franco-Pacific Thriller,' The Foreign in International Crime Writing, eds., Jean Anderson, Carolina Miranda, Barbara Pezzotti, London: Continuum Books, 2012, p. 60-71.
} 
extent, what characterises literary works authored in the French Pacific by incomers from the métropole, many of whom are in fact published in France.

To clarify the position of Franco-Pacific writers, and indigenous ones in particular, it may be useful here to turn to the concept of deterritorialisation, in the sense of the decontextualisation of an object or practice. ${ }^{11}$ One of the most obvious places for such deterritorialisation to occur is at the interface between a colonising power and a colonised territory. Rituals, traditions, cultural practices of all descriptions, viewed by the newcomer, are bereft of their contextual meaning and interpreted from an entirely different point of view. They may be exported to museums and collections of curios, where they are completely separated from their function (are deterritorialised). To illustrate this with an extreme example, we might consider the case of the New Zealand Māori tattooed heads stored in museums around the world, ${ }^{12}$ or of the head of Atai, a New Caledonian chief who was killed leading a rebellion against the French in 1878. His preserved skull was then sent to Paris for examination and classification in the laboratory of the famous anthropologist and anthropometrist Paul Broca. ${ }^{13}$ These human remains, the physical forms of people with cultural and biological ties to a particular time and place, were removed from their points of origin and relocated into a situation where they represented strangeness, otherness, difference, and-most importantly, with the latter nineteenth century's emphasis on atavism and primitive violence-a lesser degree of evolution.

Alongside this anthropometric classification went a cultural value judgment, little different from the ideas expressed in Gobineau's infamous Essay on the Inequality of Human Races (1853-55), which questioned whether non-whites were in fact 'human. ${ }^{14}$ Forms of creative expression differ widely from culture to culture. While European traditions esteem written forms over oral traditions, there is no innately logical reason to suppose a book is more durable or precious than a poem, song, prayer or genealogy committed to memory and passed down through many generations. The former is vulnerable to damp, rot, fire and other forms of destruction that can have no effect on the memorised text. To place written literatures above oral ones is merely another form of deterritorialisation, all the stronger and more harmful, perhaps, because of an underlying assumption that the invention of writing and/or printing is a sign of advancement up the evolutionary ladder.

\footnotetext{
11 Although the term is probably best-known in literary criticism as a key concept of Deleuze and Guattari (see A Thousand Plateaus, Capitalism and Schizophrenia, trans. Brian Massumi, London: Continuum Books, 1998), I am using it here in a more anthropological sense (see Thomas Barfield, ed., The Dictionary of Anthropology, Hoboken, NJ: Wiley-Blackwell, 1997, p. 370-371).

12 The return of 20 toi moko (tattooed heads) from France in January 2012 is part of an ongoing project to repatriate all Māori remains held in collections overseas. See http://www.mch.govt.nz/newsevents/ministers-releases/return-toi-moko-welcomed, accessed 28 January 2012).

${ }^{13}$ The skull was lost for many years in museum collections and having recently been rediscovered (July 2011) is now the object of demands for repatriation (December 2011). The anthropometric approach to such 'primitive' skulls is yet another example of central (European) norm opposed to marginal (primitive) variation.

${ }^{14}$ Available in English at http://archive.org/details/inequalityofhuma00gobi, accessed 10 January 2012.
} 
It is clear, however, that in order to have a presence in contemporary world literature, written texts will be the sine qua non. ${ }^{15}$

\section{Deterritorialising the written word}

There are relatively few authors in the French-speaking Pacific, no doubt as a result of some of the factors outlined above, and perhaps also because of the now almost ubiquitous presence of television. ${ }^{16}$ I will here focus on French Polynesian indigenous writers, and on one in particular whose work has from the beginning been insistent on valorising the local. The question I wish to address is whether-and if so, how-these authors are able to use the system of written literature for their own purposes. In other words, how might they in turn take a cultural form and wrench it into a new context, deterritorialising the novel or short story and reterritorialising it into some new form that takes on elements of the apparently dominated ('less-developed') culture? Only once we have considered this aspect will we be able to assess implications for the translation of these works, and for the reading of their translations.

This resistant approach to writing about their homeland or 'pays,' takes on another layer of meaning if we are aware how the equivalent Tahitian term 'fenua' is used. In addition to meaning 'land,' or 'country' (in the political sense, too, separating it from central government in France métropolitaine), it is in general use as the name of the country, Fenua, to distinguish it from the Metropole and from French-dominated terms such as Polynésie française or Porinetia farani [French Polynesia]. In New Zealand Māori (a closely-related language and culture) the term means both 'land' and 'placenta,' referring directly to the belief that people and land are indissolubly linked. Titaua Peu, in her much-acclaimed work Mutismes (2002), ${ }^{17}$ refers directly to the need to reclaim the land, reclaim the country. Moreover, she sees writing as the means to achieve this, advising her people 'Reprends tes mots / Et là, tu reprendras ta terre' [Take back your words / And at the same time you will take back your land $\left.{ }^{18}\right]$ (147).

Peu too sees the pre-existing discourses of the 'discoverers' and subsequent exoticising novelists as creating a barrier to a true reflection of local reality (27-30): when everything has been said, there appears to be no place for an authentic, indigenous voice, hence the 'mutismes' [mutenesses, silences] of her title.

\footnotetext{
${ }^{15}$ See the well-known discussion of 'world' literature by Pascale Casanova (The World Republic of Letters, trans. M. B. DeBevoise. Cambridge, MA: Harvard University Press, 2004), which proceeds from the unstated assumption that we are dealing only with print forms. We might nevertheless point out the exception of certain forms of poetry: see for example indigenous New Caledonian slam poet Paul Wamo's work (www.paulwamo.com) and his numerous performances on Youtube. The ability to see and hear such work performed before a local audience, i.e. within its context, is an exciting new development, although of course it does not at present make any provision for translation into other languages.

${ }^{16}$ While this is particularly acute in the islands, where accessing books as opposed to television is physically difficult due to distance and lack of libraries or bookshops, the publishing industry worldwide is increasingly concerned about this competition.

17 Titaua Peu, Mutismes. Papeete: Éditions Haere Po, 2002. The book is partly dedicated to the memory of Tahitian politician Pouvana'a a Oopa, imprisoned for disruptive anti-French behaviour, and perhaps because of his likely resistance to French nuclear installations in the Tuamotus.

18 All translations are my own.
} 
Chantal Spitz, in a text entitled 'l'écrire colonisé' [writing (the) colonised] in her 2006 collection of essays Pensées insolentes et inutiles, ${ }^{19}$ laments the same obstacles:

Comment écrire-parler quand les mots de l'Autre venus des cieux brumeux d'un inconnu ailleurs ont squatté mon âme. Comment parler-écrire quand la parole créatrice s'est éteinte sous la bonne parole de la frénésie évangélisatrice quand la parole libératrice s'est aliénée sous l'unique vérité des hordes colonisatrices. Comment parler-écrire quand notre imagination s'est immobilisée dans une trajectoire sans histoire quand notre essence s'est anesthésiée dans l'infinie fascination de l'Occident. Comment parler-écrire quand les hurlements de l'autre qui pense de nous pour nous parle de nous pour nous occupent l'espace nous dissocient de nous-mêmes nous folklorisent nous illusionnent. (57-58)

[How to write-speak when the words of the Other have descended from the hazy skies of some unknown elsewhere have moved uninvited into my soul. How to speakwrite when the creative word has been extinguished beneath the good word of the evangelizing frenzy when the liberating word has been alienated by the one truth of the colonizing hordes. How to speak-write when our imagination has been stopped dead in a trajectory with no history when our essence has been anesthetized before the infinite fascination of the West. How to speak-write when the shouts of the Other who thinks about us for us speaks about us for us fill up the space separate us from ourselves turn us into delusions into folklore.]

This theme of mutism, of a people reduced to silence, is continued by Moetai Brotherson in his 2007 novel, Le Roi absent. ${ }^{20}$ The first half of the book follows and is narrated by a young Tahitian, Vaki, who, despite being exceptionally gifted, chooses not to speak. While this has been described by Brotherson as a nod in the direction of the mutism of Tahitians referred to by Spitz and Peu, it can also be read as a reference to a transition from orality to a written literature, or oraliture. ${ }^{21}$ Deprived of a voice, the protagonist 'speaks' to us through the written text he leaves behind him. Brotherson's novel, however, while it apparently promotes a narrative of successful indigenous conversion to Eurocentric values, notably via the educational and social success of Vaki, also undermines that trajectory. ${ }^{22}$ To avoid giving too much of the plot away, I will

\footnotetext{
${ }^{19}$ Chantal Spitz, Pensées insolentes et inutiles. Papeete: Éditions te ite, 2006. The book contains essays written between 1990 and 2002, many of which appeared in the review Littérama'ohi, of which Spitz is a founding editor.

${ }^{20}$ Moetai Brotherson, Le Roi absent. Papeete: Au Vent des îles, 2007..

${ }^{21}$ Most famously treated, in the Tahitian context, by Flora Devatine: see her Tergiversations et rêveries de l'écriture orale, Te Pabu a Hono'ura, Papeete: Au Vent des îles, 1998. Brotherson's author description on the website of his publisher Au Vent des îles refers to the relationship between oral tradition and writing: 'Paradoxalement, il écrit par amour de l'oralité, considérant que le livre n'est que la partition d'une mélodie que chaque lecteur est libre d'interpréter' [Paradoxically, he writes out of a love for orality, seeing the book as a musical score that each reader is free to interpret], http://www.auventdesiles.pf/nos-auteurs/174brotherson-moetai.html, accessed 28 January 2012.

22 See also Jean Anderson, 'What's so Funny About That? On Translating (Post)colonial Humour - the Case of Moetai Brotherson's Le Roi absent in Creative Constraints: Translation and Authorship, eds. Rita Wilson and Leah Gerber, Melboune, Monash UP, 2012, p. 103-117.
} 
simply comment that the destabilising aspects of mimicry pointed out by Homi Bhabha ${ }^{23}$ are here deployed to the full in a plot that initially (ostensibly) elevates French values only to unravel them in its later stages.

It should be clear from this discussion, and from the brief quotations given so far, that a number of Tahitian authors are working deliberately to elaborate a resistant literature that 'writes back. ${ }^{24}$ This means, among other things, that these writers and their texts share elements of resistance with other postcolonial writers, ${ }^{25}$ not just those who write in French (Chamoiseau, Confiant, Glissant, Senghor, Condé, Djebar, for example) ${ }^{26}$ but also with anglophone authors, especially those from the Pacific with whom they have cultural, ethnic, linguistic or historical links: here we might think of Albert Wendt, Patricia Grace, Witi Ihimaera, John Pule, Anita Heiss, Terri Janke, Tara June Winch and others.

While the Pacific is a vast and immensely varied region, there are commonalities such as these which mean francophone and anglophone authors could engage in an enriching dialogue. Within the framework of Pacific studies, however, the bulk of scholarship to date is largely limited to work available in English, with some notable exceptions (Gorodé, Spitz-and in these cases the availability of even limited translated material has made a significant difference). ${ }^{27}$ Despite the early French-language contributions of writers such as Senghor, Césaire and Damas, who originated the term and concept of négritude in the 1930s, and of Fanon in the 1950s, the academic approach known as postcolonial studies has been somewhat slow to take hold in France. ${ }^{28}$

Given the relative lack of interest in Pacific writing and writers within the métropole, then, along with the regional connections between anglophone and francophone Pacific cultures underlined by Keown, what is or should be the role of translation between anglophone and francophone Pacific literatures? Translators, like any other readers, are caught between the urge to underline the human universals in the works they translate and the need to respect local specificities the writer may have wished to emphasise. The debate between domestication and foreignisation, the acknowledgment of the degree of

\footnotetext{
${ }^{23}$ Homi Bhabha, 'Of Mimicry and Man: The Ambivalence of Colonial Discourse,' in The Location of Culture. London: Routledge, 1994, p. 85-92.

${ }^{24}$ To use the expression consecrated by Bill Ashcroft, Gareth Griffiths and Helen Tiffin's title The Empire Writes Back: Theory and Practice in Postcolonial Literatures. London: Routledge, 1989.

25 Although we should bear in mind that for many, French Polynesia is not as yet post colonisation.

${ }^{26}$ I list these authors together here not with any intention of implying they form a homogenous group, but rather the contrary, i.e. that they can be seen to represent the exciting diversity of writing with a postcolonial context.

${ }^{27}$ See Michelle Keown, 'Littérature-monde or Littérature océanienne? Internationalism versus Regionalism in Francophone Pacific Writing,' in Transnational French Studies: Postcolonialism and Littérature-monde, eds. Alec G. Hargeaves, Charles Forsdick and David Murphy, Liverpool: Society for Francophone Postcolonial Studies / Liverpool University Press, 2010, p. 240-257.

${ }^{28}$ For example, one of the most-cited texts in the domain, Edward Said's Orientalism (New York: Vintage, 1978), although translated into French by Catherine Malamoud as L'Orientalisme. L'Orient créé par l'Occident, (Paris: Editions du Seuil, 1980) did not make the same kind of impact within French academic circles as it had in anglophone studies, and Bhabha's 1994 The Location of Culture was not translated until 23 years later (Les Lieux de la culture, trans. Françoise Bouillot, Paris: Payot, 2007).
} 
deterritorialisation of the writing are of the utmost importance. An indigenous-authored novel is not necessarily a sign that the writer has stepped onto the rungs of a Eurocentric ladder; he or she may instead be twisting that ladder into a more culturally familiar shape, in other words deterrorialising it. Not to recognise this is to misread not only the text but its context. The translator should ideally be aware of the deterritorialising aspects and give them priority. In practical terms, this means highlighting the indigenous/colonial interface, with the aid of paratextual materials such as prefaces, translators' notes, and/or glossaries if these are feasible. ${ }^{29}$ Including such elements may be outside the translator's control, for example where the publisher's protocols mandate a particular strategy.

Perhaps the most striking example of a deterritorialising Pacific writer in French is Chantal Spitz. Not only does her work cross (European-originated) genre boundaries, ${ }^{30}$ as we shall see, she also bends the French language to her purposes, rendering it strange in ways that are seldom seen within the realm known as "francophone writing. ${ }^{31}$ In her novel L'île des rêves écrasés she does not hesitate to move between prose and poetry, as her characters express their feelings of pain and exclusion: even experienced Pacific Studies readers such as the reviewer of the translated version, Paul Sharrad, appeared to find this slippage difficult, referring to a resemblance with Broadway musicals. ${ }^{32}$ To my mind, Spitz has deliberately broken one of the rules of the novel by including essentially oral forms of communicating deeply-felt emotions: to equate this with a quintessentially American form of popular culture is to read the work outside its own frame. This is not the only way in which Spitz challenges individual readers, and, more generally, Eurocentric practices. The subtitle of her second book, Hombo, transcription d'une biographie, ${ }^{33}$ can be read as a further indication of her desire to fracture generic boundaries. What does 'transcription of a biography' actually mean? Are not all biographies transcriptions? Or is there an implication that biographies are quintessentially oral, stories narrated between generations?

In instances like this, the translator's task is not too complex: the linguistic gap can be bridged and still carry the same deterritorialising implications. Where the author has chosen to undermine the grammatical and syntactical foundations of the French language itself, however, the challenge is much greater. Statements of deeply-held political beliefs

\footnotetext{
${ }^{29}$ I am personally loathe to create academically-encrusted texts, preferring to steer the potential reader with as light a hand as possible so as to preserve the literary nature of the original, and trusting to readers' abilities to do some of their own research via the rapidly expanding resources of the internet. I do acknowledge that removing texts from their source readership context alters the original situation of postcolonial resistance and that this shift can and often should be taken into account in facilitating target culture reading, for example by including a glossary where the original had none.

${ }^{30}$ See Jean Anderson, 'Translating Chantal Spitz: Challenges of the Transgeneric Text.' Australian Journal of French Studies 50 (2), 2013: 177-188.

${ }^{31}$ Despite the debate around 'créolité' promoted by Glissant, Chamoiseau and Bernabé, as Paul Bandia has pointed out, the French education system in the colonies and the publishing industry have been highly focused on grammatical 'correction' (Translation as Reparation: Writing and Translation in Postcolonial Africa. Manchester: St Jerome, 2008, p. 27-28). Published Tahitian texts generally use a very standardised French, with the exception of Spitz and some poetic works.

32 Paul Sharrad, 'Review of Island of Shattered Dreams, by Chantal T Spitz.' The Contemporary Pacific 21 (1) 2009: 190-192. See also Keown's analysis of the review, op. cit., p. 191-192.

${ }^{33}$ Chantal Spitz, Hombo: transcription d'une biographie. Papeete: Au Vent des îles, 2012 (2002).
} 
may be written in an intensely poetic style, such as the extract from 'l'écrire colonisé' quoted above, or poetry may intrude ${ }^{34}$ into novels, as was the case with L'îles des rêves écrasés, or with her most recent work, Elles: Terre d'enfance, roman à deux encres. ${ }^{35}$ The 'deux encres' (two inks, two pens) in question are two very different styles or (written) voices, one much less idiosyncratic than the other, using relatively short sentences and relatively normal syntax and grammar. The second is a very poetic and intense voice, largely unpunctuated but laid out on the page like verse, and featuring some of Spitz's favourite stylistic devices (alliteration and assonance, punning, a driving rhythm created by double and triple repetitions that function within the text almost like echoes):

Nos conversations murmurées au soir de sa vie m’ont été fécondations dépouillées frondaisons dévoilées fermentations déployées

je découvrais au travers de ses remémorations mes genèses mes hasards mes essors ses promesses ses défaites ses fortunes

ma conscience se posait se pausait

j'assemblais mes bouts d'inconscience mes lambeaux d'inexistence mes miettes d'indigence dans une lucidité sans rivage

je convergeais vers l'origine de nos carences la source de nos absences le fait de nos béances pour féconder une histoire faite d'aubes et de ténèbres de confiances et de cuirasses de clémences et de glaces

elle

ma mère

I have argued elsewhere for the need in translating postcolonial texts to respect the transgressive nature of the writing, whatever form that transgression might take. ${ }^{36}$ Yet again, Spitz challenges the reader by crossing genre boundaries, deterritorialising the 'novel' announced in the title on the cover, and shaping her own narrative, a mixture of prose and poetry, of diegesis and almost exegetic elaboration. Perhaps more importantly, she works sound and rhythm with great intensity, rejecting more conventional (written) punctuation in favour of a breath-controlled flow that becomes evident if the text is read aloud. This oral/aural style amounts to an innovative and idiosyncratic use of French which is not for one moment to be confused with the kind of oral-therefore-casual-andinferior label that eurocentric thinkers tend to affix to texts that feature 'orality.' This is the highly polished product of a long and ongoing experiment with language and

\footnotetext{
${ }^{34}$ I use this term to underline an outsider / European understanding of the generic boundaries between the two.

${ }^{35}$ Chantal Spitz, Elles: Terre d'enfance, roman à deux encres. Papeete: Au Vent des îles, 2011.

${ }^{36}$ See 'La Traduction résistante: Some Principles of Resistant Translation of Anglophone and

Francophone Pacific Literature' in Cultural Crossings / À la croisée des cultures. Negotiating Identities in Francophone and Anglophone Pacific Literatures / De la négociation des identités dans les littératures francophones et anglophones du Pacifique, ed., Raylene Ramsay. Peter Lang: Brussels, 2010, p. 285-300.
} 
narrative form by a writer searching for the 'écrire-parler' and 'parler-écrire' she signalled in 'écrire colonisé'.

Other Pacific writers have not necessarily adopted the same strategies as Spitz: Patricia Grace, for example, as early as Mutuwhenua: the Moon Sleeps (1978) ${ }^{37}$ refers to the habit of Māori elders of providing information in pieces rather than in a logical, linear fashion: in Baby No-Eyes (1998) ${ }^{38}$ she refers more explicitly to the elders' way of telling stories in an elliptical and circular fashion. As a result, she structures her own narratives in non-linear ways that leave the reader guessing until resolution is achieved. Titaua Peu mingles fiction and historical fact in a 'novel' that strategically uses spoken forms of French ('je sais pas' systematically replaces the more usual written form 'je ne sais pas'), and Moetai Brotherson deliberately blurs the boundaries between 'facts' (events in a fictional narrative generally presented as having happened) and delusions, to the extent that the conventional suspension of disbelief necessary for the reading of fiction is confronted by the book's apparent contradictions.

In quite different ways, but with similar effect, these writers deterritorialise narrative and reterritorialise it into new forms that flout the traditional European distinctions between fiction and reality, oral and literary. Whether they write in French from the French Pacific or in English from New Zealand, they have a great deal of common ground - their Pacific origins, the loss of land, language, and traditions - which makes it imperative to translate their texts and thus assist in the sharing of their literary responses, experiments and innovations.

${ }^{37}$ Patricia Grace, Mutuwhenua: the Moon Sleeps, Auckland: Penguin, 1998.

${ }^{38}$ Patricia Grace, Baby No-Eyes, Auckland: Penguin, 1998. 


\section{REFERENCES}

Anderson, Jean. 'Seeing Double: Representing Otherness in the Franco-Pacific Thriller,' eds. Jean Anderson, Carolina Miranda and Barbara Pezzotti. The Foreign in International Crime Writing, London: Continuum Books, 2012, p. 60-71.

Anderson, Jean. 'La Traduction résistante: Some Principles of Resistant Translation of Anglophone and Francophone Pacific Literature,' ed. Raylene Ramsay, Cultural Crossings / À la croisée des cultures. Negotiating Identities in Francophone and Anglophone Pacific Literatures / De la négociation des identités dans les littératures francophones et anglophones $d u$ Pacifique, Brussels: Peter Lang, 2010, p. 285-300.

Anderson, Jean. 'Translating Chantal Spitz: the Challenges of Transgeneric Text,' Australian Journal of French Studies, 50 (2) 2013: 177-188.

Anderson, Jean. 'What's So Funny About That? On Translating (Post)colonial Humour the Case of Moetai Brotherson's Le Roi absent, eds. Rita Wilson and Leah Gerber. Creative Constraints: Translation and Authorship. Melbourne: Monash University Press, 2012, p. 103-117.

Ashcroft, Bill, Gareth Griffiths and Helen Tiffin. The Empire Writes Back: Theory and Practice in Postcolonial Literatures. London: Routledge, 1989.

Auzas, Noémie. Chamoisean ou les voix de Babel. Paris: IMAGO, 2009.

Bandia, Paul. Translation as Reparation: Writing and Translation in Postcolonial Africa. Manchester: St Jerome, 2008.

Barfield, Thomas, ed. The Dictionary of Anthropology. Hoboken, NJ: Wiley-Blackwell, 1997.

Bhabha, Homi. 'Of Mimicry and Man: the Ambivalence of Colonial Discourse. The Location of Culture. London: Routledge, 1994, p. 85-92. (Les Lieux de la culture, trans. Françoise Bouillot. Paris: Payot, 2007).

BPANZ. 'Featured Members: Robyn Bargh.'

http://bpanz.org.nz/cms/index.php?option=com content\&view =article\&id=149:fe atured-member-robyn-bargh-huia-publishers\&catid=23:members, accessed 12 January 2012.

Brotherson, Moetai. 'Author note.' http://www.auventdesiles.pf/nos-auteurs/174brotherson-moetai.html, accessed 28 January 2012.

Brotherson, Moetai. Le Roi absent. Papeete: Au Vent des îles, 2007. (The Missing King, trans. Jean Anderson. Auckland: Little Island Press, 2012. 
Casanova, Pascale. The World Republic of Letters, trans. M. B. DeBevoise. Cambridge, MA: Harvard University Press, 2004.

Deleuze, Gilles and Félix Guattari. Mille Plateaux. Paris: Minuit, 1980.

Deleuze, Gilles and Felix Guattari. A Thousand Plateaus, Capitalism and Schirophrenia, trans Brian Massumi, London: Continuum Books, 1998.

Deleuze, Gilles, Félix Guattari and Robert Brinkley. 'What is a Minor Literature?' Mississippi Review, 11 (3) 1983: 13-33. http://www.jstor.org/pss/20133921, accessed 10 December 2011.

Devatine, Flora. Tergiversations et rêveries de l'écriture orale, Te Pahu a Hono'ura. Papeete: Au Vent des îles, 1998.

Gobineau, Arthur de. Essay on the Inequality of Human Races. http://archive.org/details/inequalityofhuma00gobi, accessed 10 January 2012.

Grace, Patricia. Baby No-Eyes. Auckland: Penguin, 1998 (1978).

Grace, Patricia. Mutuwhenua: the Moon Sleeps. Auckland: Penguin, 1998.

Hau'ofa, Epeli. 'Our Sea of Islands,' eds. Eric Waddell, Vijay Naidu and Epeli Hau'ofa. A New Oceania: Rediscovering Our Sea of Islands. Suva: University of the South Pacific Press, p. 2-16.

Keown, Michelle. 'Littérature-monde ou Littérature océanienne? Internationalism versus Regionalism in Francophone Pacific Writing,' eds. Alec G. Hargeaves, Charles Fosdick and David Murphy, Transnational French Studies: Postcolonialism and Littératuremonde. Liverpool: Society for Francophone Postcolonial Studies/Liverpool University Press, 2010, p. 240-257.

Ministry of Culture and Heritage. 'Return of Toi moko Welcomed.' http://www.mch.govt.nz/news-events/ministers-releases/return-toi-mokowelcomed, accessed 28 January 2012.

Peu, Titaua. Mutismes. Papeete: Editions Haere Po, 2002.

Reitzig, Andreas. 'National Identity and New Zealand's Ties With Oceania.' Seminar, April 13, 2011. Victoria University of Wellington.

Said, Edward. Orientalism. New York: Vintage, 1978. (L’Orientalisme: l'Orient créé par l'Occident, trans. Catherine Malmoud. Paris: Seuil, 1980). 
Sharrad, Paul. 'Review of Island of Shattered Dreams, by Chantal T. Spitz.' The Contemporary Pacific 21 (1) 2009: 190-192.

Spitz, Chantal. Elles: Terre d'enfance, roman à deux encres. Papeete: Au Vent des îles, 2011.

Spitz, Chantal. L'Ile des rêves écrasés. Papeete: Au Vent des îles, 2012 (1991). (Island of Shattered Dreams, trans. Jean Anderson. Wellington: Huia Books, 2007).

Spitz, Chantal. Hombo: Transcription d'une biographie. Papeete: Au Vent des îles, 2012 (2002).

Spitz, Chantal. Pensées insolentes et inutiles. Papeete: Editions te ite, 2006.

The Telegraph. 'Cannibal Fear over German Tourist.' http://www.telegraph.co.uk/news/worldnews/australiaandthepacific/frenchpolynesi atahiti/8830733/Cannibal-fear-over-German-tourist.html, accessed 10 December 2011. 